\title{
PERANAN MASJID JAMIK AL-HIDAYAH BATUMARTA DALAM MENANAMKAN NILAI- NILAI KEISLAMAN DI DESA MARTAJAYA
}

\author{
P-ISSN: 2085-4536 | E-ISSN: 2721-7183 \\ Link: https://jurnal-stidnatsir.ac.id/index.php/binaummat/article/view/53 \\ DOI : https://doi.org/10.38214/jurnalbinaummatstidnatsir.v2i02.53 \\ Dikirim: 25-03-2019 \\ Direview: 05-04-2019 \\ Diterbitkan: 17-04-2019 \\ AFIATUN NUFUS \\ Mocimoci707@gmail.com \\ STID Mohammad Natsir - Indonesia \\ SALMAN ALFARISI \\ salman@stidnatsir.ac.id \\ STID Mohammad Natsir - Indonesia
}

\begin{abstract}
ABSTRAK
Tujuan penelitian: Untuk mengetahui Peranan Masjid Jamik Al-Hidayah Batumarta Dalam Menanamkan Nilai-Nilai Keislaman di Desa Martajaya. Metode penelitian: Kualitatif. Hasil penelitian, Masjid Jamik AlHidayah memiliki peranan yang posistif Dalam Menanamkan Nilai-Nilai Keislaman di Desa Martajaya. Indikasi ini dapat ketahui dari Pertama, Harapan tentang peranan (Expectation), yaitu adanya harapan masyarakat kepada Masjid Jamik Al-Hidayah untuk tetap mengembangkan da'wahnya dalam menjalankan peranannya menanamkan nilai-nilai keislaman di Desa Martajaya baik dari segi Akidah, syariah maupun akhlak, melalui pendidikan anak-anak, kajian-kajian rutin atau kegiatan-kegiatan lain yang diselenggarakan. Kedua, dari aspek Norma yaitu berjalannya programprogram yang diselenggarakan oleh masjid telah membawa pengaruh dan telah membentuk suatu norma atau kebiasan baru yang baik pada masyarakat. Ketiga. Performance (wujud prilaku) yaitu berjalanya programprogram yang telah terselenggara di Masjid Jamik AL-Hidayah Batumarta.
\end{abstract}

Kata Kunci: Peranan Masjid, nilai-nilai keislaman, menanamkan nilai

\section{PENDAHULUAN}

Masjid memiliki peran dan fungsi yang penting dalam kehidupan umat Islam. Selain fungsi utamanya sebagai tempat beribadah, masjid juga dapat digunakan sebagai sentral da'wah. Seperti pada zaman Rasulullah 
Muhammad Shalallabu 'alaibi wa salam. Ketika pertama kali tiba di kota Madinah pada waktu itu bernama Yastrib, langkah pertama yang beliau ambil adalah membangun masjid.

Masjid itu bukan sekedar tempat untuk melaksanakan shalat, tetapi juga merupakan sekolahan bagi orang-orang muslim untuk menerima pengajaran Islam dengan dibimbing oleh nabi, sebagai balai pertemuan dan tempat untuk mempersatukan berbagai unsur kekabilahan dan sisa-sisa pengaruh perselisihan semasa jahiliyah, sebagai tempat untuk mengatur segala urusan sekaligus sebagai gedung parlemen untuk bermusyawarah dan menjalankan pemerintahan. ${ }^{1}$

Dilihat dari sisi pertumbuhan masjid di Indonesia sangat menggembirakan. Dari tahun ketahun jumlah masjid kian bertambah. Tetapi, kenyataannya masih banyak pengurus masjid yang kurang mengoptimalkan fungsi masjid itu sendiri. Karena itu, memfungsikannya secara maksimal harus terus menerus dilakukan. Kondisi masyarakat lingkungan masjid harus mendapat perhatian dalam rangka menyusun program kegiatan. Masjid di desa mungkin akan berbeda tekanan programnya dengan masjid di kota. ${ }^{2}$

Disinilah pengurus masjid yang menjadi jamaah inti memegang peran penting dalam mengfungsikan masjid. Mengfungsikan masjid bukan hanya sebagai tempat beribadah. Akan tetapi sebagai sarana untuk meningkatkan kehidupan, kualitas umat dan masyarakat.

Potensi ini hanya dapat terwujud dengan menejemen masjid yang professional. Tanpa ditangai secara professional maka masjid hanya merupakan monument dan kerangka bangunan yang mati yang tidak dapat memancarkan perjuangan syiar dan penegakan risalah kerasulan. ${ }^{3}$

Masjid Jami’ Al-Hidayah adalah salah satu masjid yang berupaya untuk mengoptimalkan fungsinya untuk menamkan nilai-nilai keislaman kepada masyarakat di Desa Martajaya .

\footnotetext{
${ }^{1}$ Syaikh Shafiyurrahman Al-Mubarakfuri, Ar-Rahiq Al-Makhtum, Jakarta Timur: Pustaka Al-Kautsar, 2012, Cet 37, hal. 206

${ }^{2}$ Didin Hafifuddin, Dakwah Aktual, hal. 173

${ }^{3}$ Sofyan Syafri Harahap, Menejemen Masjid, Yogyakarta: PT. Dana Bhakti Wakaf, 1993, Hal. 6
} 
Masjid Al-Hidayah berupaya untuk membawa perkembangan kegiatan keagamaan di Desa Martajaya dengan menamkan nilai-nilai keislaman kepada masyarakat. Dimulai dari pusat pendidikan tahfidz bagi anak-anak usia sekolah, tempat menimba ilmu bagi seluruh masyarakat baik itu ibu-ibu, seperti kajian rutin bulanan tentang fiqh, kajian remaja setiap malam ahad, dan kajian umum rutin setiap harinya dimulai ba'da magrib hingga isya'. Masjid Jamik Al-Hidayah Batumarta juga memiliki program bulanan yaitu Tabligh Akbar dan program tahunan seperti penyelenggaraan shalat tarawih dilaksanaakan sebanyak dua kali dalam satu malam. Hal tersebut merupakan keunggulan yang dimiliki oleh Masjid Jamik AlHidayah Batumarta. Terlebih lagi masjid ini dinobatakan sebagai masjid kecamatan dan pada tahun 2015 menjadi masjid teladan ke dua sekabupaten Ogan Komering Ulu.

Masjid Jamik Al-Hidayah Batumarta telah mengubah pola pikir masyarakat yang menganggap bahwa masjid hanya tempat Shalat melainkan masjid adalah sarana perkembangan syiar agama Islam di desa Martajaya yang dimanfaatkan sebagai sarana belajar baik remaja, anak-anak maupun orangtua. Hal ini dapat menjadi pelajaran bagi pengurus masjid lainnya dalam mengoptimalkan fungsi masjid sebagai sarana membentuk masyarakat yang islami. Oleh karena itu peneliti, tertarik untuk melakukan penelitian dengan judul "Peranan Masjid Jamik Al-Hidayah Batumarta Dalam Menanamkan Nilai-Nilai Keislaman di Desa Martajaya"

\section{Pengertian Peranan}

Dalam kamus besar bahasa Indonesia kata peranan berasal dari kata peran yang berarti pemain sandiwara. Sedangkan peranan adalah sesuatu yang menjadi bagian atau yang memegang pemimpin yang terutama dalam terjadinya hal atau peristiwa. ${ }^{4}$ Kata peran yang juga mempunyai arti bagian yaitu dari tugas utama yang harus dilakukan. ${ }^{5}$

\footnotetext{
${ }^{4}$ Tim Pustaka Phoenix, Kamus Besar Bahasa Indonesia Edisi Baru, Jakarta: Pustaka Phoenix, 2009, hal. 652

${ }^{5}$ Departemen pendidikan dan budaya, Kamus Besar Bahasa Indonesia, Jakarta: Balai Pustaka, 1988, hal. 751
} 
Grass Massam dan A. W.M.C Eachern sebagaimana dikutip oleh David Berry, mendefinisikan peranan sebagai perangkat harapan-harapan yang dikenalkan pada individu yang menempati kedudukan sosial tertentu. ${ }^{6}$

Menurut Soerjono Soekanto, peranan mencakup tiga hal ${ }^{7}$, yaitu:

a. Peranan meliputi norma-norma yang dihubungkan dengan posisi atau tempat seseorang dalam masyarakat. Dalam arti ini peranan diartikan sebagai rangkaian peraturan-peraturan yang membimbing seseorang dalam kehidupan kemasyarakatan.

b. Peranan adalah suatu konsep tentang apa yang dapat dilakukan oleh individu dalam masyarakat sebagai organisasi.

c. Peranan yang dapat dikatakan sebagai perilaku individu yang penting bagi struktur sosial masyarakat.

Ada sebuah teori dalam peranan yang dikenal dengan teori peran atau (Role Theory) merupakan perpaduan berbagai teori, orientasi maupun disiplin ilmu. Selain dari psikologi, teori peran berawal dari dan masih tetap digunakan dalam sosiologi dan antropologi. Dalam ketiga bidang ilmu tersebut, istilah "peran" diambil dari dunia teater. Dalam teater, seorang aktor harus bermain sebagai seorang tokoh tertentu dan dalam posisinya sebagai tokoh itu ia diharapkan untuk berprilaku secara tertentu. ${ }^{8}$

Posisi aktor dalam teater kemudian dianalogikan dengan posisi seorang dalam masyarakat. yaitu bahwa perilaku yang diharapkan dari seorang aktor atau seorang dalam masyarakat tidak berdiri sendiri, melainkan selalu berada dalam kaitan orang-orang lain yang berhubungan dengan aktor atau seorang dalam masyarakat tersebut. Dari sudut pandangan inilah disusun teori-teori peran. ${ }^{9}$

Dalam sebuah teori Biddle \& Thomas membagi peristilahan dalam teori peran dalam empat golongan, yaitu istilah-istilah yang menyangkut: Orang-orang yang mengambil bagian dalam interaksi social, perilaku yang

${ }^{6}$ N. Grass, W. S. Masson and A.w.m.c. Eachern, Exploration Role Analysis, dalam david Berry, Pokok-pokok Pikiran dalam Sosiologi, Jakarta: Raja Grafindo Persada, 1995, cet. III, hal, 99 2009 , hal, 212

${ }^{7}$ Soerjono Soekanto, Sosiologi Suatu Pengantar, Jakarta: Rajawali Pers,

${ }^{8}$ Sarlito Wirawan Sarwono, Teori-teori Psikologi Sosial, Jakarta: PT Raja Grafindo Persada, 2017, Cet. XVII, hal. 215

${ }^{9}$ Sarlito Wirawan Sarwono, Teori-teori Psikologi Sosial, hal. 215 
muncul dalam interaksi tersebut, kedudukan orang-orang dalam perilaku dan kaitan antara orang dan perilaku.

Orang yang mengambil interaksi sosial dapat dibagi dalam dua golongan yang pertama adalah aktor (actor,pelaku) orang yang sedang berprilaku menuruti suatu peran tertentu dan yang kedua adalah target (sasaran) atau orang lain yang mempunyai hubungan dengan aktor dan perilakunya. Aktor maupun target bisa berupa individu-individu ataupun kumpulan individu (kelompok). ${ }^{10}$

Menurut Biddle dan Thomas ada lima istilah tentang perilaku dalam kaitannya dengan peran:

a. Expectation (harapan)

Harapan tentang peran adalah harapan-harapan orang lain tetang prilaku yang pantas, yang seyogianya ditunjukkan oleh seorang yang mempunyai peran tertentu. Sebagai contoh masyarakat umum, pasienpasien, dan orang-orang sebagai individu mempunyai harapan tertentu tentang prilaku yang pantas dari seorang dokter.

Harapan tersebut berlaku umum segolongan orang berharap dokter harus bisa menyembuhkan orang sakit, golongan yang lain memiliki harapan agar dokter bisa juga memberikan nasihat-nasihat tentang persoalan rumah tangga selain menyembuhkan dari penyakit.

b. Norm (norma)

Menurut Secord dan Backman norma hanya merupakan salah satu bentuk harapan. Ada dua jenis harapan menurut Sacord dan Backman bersifat meramalkan dan harapan normatif. Selanjutnya Biddle dan Thomas membagi harapan normatif menjadi dua jenis ${ }^{11}$ :

1) Harapan yang terselubung yaitu harapan yang tetap ada walaupun tidak diucapkan. Misalnya dokter harus menyembuhkan pasien, guru harus mendidik murid-muridnya. Inilah yang disebut norma.

2) Harapan yang terbuka yaitu harapan yang diucapkan. Misalnya ayah meminta anaknya untuk menjadi anak yang bertanggung jawab dan rajin belajar. harapan jenis ini dinamai tuntutan peran. Tuntutan

\footnotetext{
${ }^{10}$ Sarlito Wirawan Sarwono, Teori-teori Psikologi Sosial, hal 216

${ }^{11}$ Sarlito Wirawan Sarwono, Teori-teori Psikologi Sosial, hal 218
} 
peran melalui proses internalisasi dapat menjadi norma bagi peran yang bersangkutan.

c. Performance (wujud prilaku)

Wujud prilaku dalam peran diwujudkan dalam prilaku aktor. Berbeda dari norma, wujud prilaku ini nyata, bukan sekedar harapan. Dan berbeda pula dari norma, prilaku yang nyata ini bervariasi. Variasi dalam teori peran dipandang normal dan tidak ada batasnya. Sebagai contoh peran seorang ayah seperti yang diharapkan oleh norma adalah mendisiplinkan anaknya. Akan tetapi dalam kenyataannya cara mendisplinkan anak antara ayah satu bisa berbeda dengan ayah yang lain.

d. Evaluation (penilaian) dan Sanction (sanksi)

Penilaian dan sanksi sulit untuk dipisahakan pengertiannya jika dikaitkan dengan peran. Menurut Biddle dan Thomas kedua hal tersebut didasarkan pada harapan masyarakat (orang lain) tentang norma. Berdasarkan norma tersebut orang memberikan kesan positif atau negatif terhadap suatu prilaku. Kesan negatif atau positif inilah yang dinamakan penilaian peran. Sedangkan yang dimaksud dengan sanksi adalah usaha orang untuk mempertahankan suatu nilai positif agar perwujudan peran diubah sedemikian rupa sehingga hal yang tadinya dinilai negative bisa menjadi positif.

\section{Pengertian Masjid}

Menurut bahasa, Lafazh مَسْجْدُ mengikuti pola lafazh مَفَعِ yang artinya nama untuk tempat sujud. ${ }^{12}$

Firman Allah dalam Al-Qur'an surat al-Jin ayat 18:

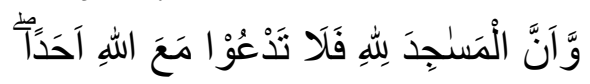

"Dan Sesunggubnya mesjid-mesjid itu adalab kepunyaan Allah. Maka janganlah kamu menyembah seseorangpun di dalamnya di samping (menyembah) Allab".

12، Abdullah bin Shalih al-Fauzan, Buku Pintar Masjid, Jakarta: Pustaka Imam Asy-Syafi' I, 2011, hal. 9 
Secara harfiah, sebagaimana banyak dipahami bahwa masjid merupakan sebuah kata yang terbentuk dari bahasa Arab sajada-yasjudu yang artinya bentuk penyerahan diri. Sebuah penghambaan makhluk kepada sesuatu yang dianggap lebih Maha Berkuasa atas segala hal. Dari kata-kata tadi timbul istilah antara lain; sujud- posisi mencium bumi seraya menghadap sesuatu yang dianggap besar tadi; sajadah- benda yang biasa dijadikan sebagai alas untuk bersujud dalam shalat. Satu kata lagi yang terbentuk dari kata dasar tadi ialah masjid yang dalam gramatika bahasa Arab berada pada posisi isim makan yang menunjukkan tempat. Dari makna tersebut telah dapat dipahami bahwa masjid tidak lain berfungsi sebagai tempat bersujud seorang hamba sebagai bukti penyerahan diri kepada Sang Khalik.. ${ }^{13}$

Dalam pengertian sehari-hari, masjid adalah bangunan untuk shalat kaum muslimin. ${ }^{14}$ lebih spesifik lagi masjid adalah bangunan, gedung atau sesuatu lingkungan yang berpagar sekelilingnya yang didirikan secara khusus sebagai tempat beribadah kepada Allah, khususnya ibadah shalat, berzikir kepada Allah. ${ }^{15}$

\section{Peran dan Fungsi Masjid}

Ada beberapa fungsi masjid dalam lingkungan masyarakat Islam, fungsi tersebut dapat dikategorikan menjadi dua jenis, yakni primer dan sekunder. Fungsi primer yang dimaksud ialah sebagai tempat ibadah yang bersifat ritual; seperti shalat, i'tikaf, dan sebagainya. Sedangkan yang bersifat sekunder ialah segala kegiatan yang memiliki dimensi muamalah yang berkenaan dengan hubungan sesame anggota masyarakat yang ada dilingkungan masjid tersebut yang secara substansial sesungguhnya masih merupakan bentuk ibadah juga. Secara menyeluruh kedua kategori inilah yang melengkapi dan oleh karenanya merupakan fungsi yang terintregitasi dan bersifat komplementer.

Dalam buku menejemen masjid, karya A. Bachrun Rifa'i dituliskan ada beberapa fungsi masjid diantara adalah sebagai berikut:

\footnotetext{
${ }^{13}$ A. Bachrun Rifa'I dan Moch. Fakhruroji, Menejemen Masjid, Bandung: Benang Merah Press, 2005, hal.9

${ }^{14}$ Bidang Pemberdayaan Daerah \& Kerjasama Dalam Negri Dewan Da'wah Islamiyah Indonesia, Panduan Pengelolaan Masjid \& Islamic Centre, Jakarta: 2013, hal. 2

${ }^{15}$ Ibid., hal. 3
} 
a. Masjid Sebagai Tempat Shalat

Sesuai dengan namanya masjid adalah tempat sujud, makna fungsi utamanya adalah sebagai tempat ibadah shalat, maka ibadah dalam Islam cukup luas, yaitu menyangkut segala aktivitas kehidupan yang ditujukan untuk memperoleh ridha Allah, maka fungsi masjid di samping sebagai tempat shalat juga sebagai tempat beribadah secara luas sesuai dengan ajaran Islam. ${ }^{16}$ Dalam AlQur'an surat An-Nur ayat 36:

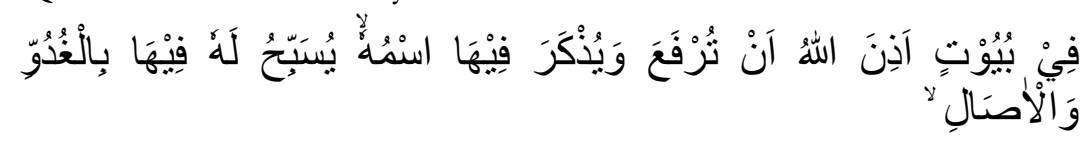

"Bertasbih kepada Allah di masjid-masjid yang telah diperintabkan untuk. dimuliakan dan disebut nama-Nya di dalamnya, pada waktu pagi dan waktu petang"

b. Sosial Kemasyarakatan

Tujuan utama Islam berkumpul di masjid ternyata tidak hanya untuk melaksanakan shalat semata, dalam pertemuan tersebut muncul proses komunikasi dan interaksi untuk membicarakan hal-hal yang berhubungan dengan kepentingan bersama. Hal ini lama kelamaan membentuk suatu ikatan emosional dan membentuk kesatuan sosial diantara mereka, yaitu kesatuan sosial Muslim. Kesatuan Muslim ini bisa diterapkan sebagai kesatuan masyarakat yang tersusun rapi dan terorganisir, yaitu masyaakat. ${ }^{17}$

Sebagai makhluk sosial, manusia terbatas oleh kekurangan sekaligus kelebihannya. Hal inilah yang menyebabkan manusia hidup bermasyarakat, satu sama lain saling mengadakan interaksi untuk memenuhi masing-masing kebutuhannya. Di sisi lain, kita melihat masjid sebagai sebuah pranata sosial yang bertujuan untuk memenuhi berbagai kebutuhan yang mendasar itu. Oleh karena itu

\footnotetext{
${ }^{16}$ Sudirman H. Makka, Rekonstruksi Menejemen Masjid dan Peran

Kelebean, Bima: Pemda Kabupaten Bima, 2016, Cet 1, hal. 26

${ }^{17}$ H. Mahmud Hamundu, Pedoman Menejemen Organisasi Jamaah Masjid, hal. 52
} 
dalam fungsinya sebagai prenatal sosial umat Islam, masjid kemudian menempati peran penting dalam menyelenggarakan konsolidasi sesama umat Islam untuk bersama-sama memecahkan persoalan yang mereka hadapi dalam masyarakat. ${ }^{18}$

Dari perkumpulan dan hubungan sosial itulah kemudian berkembang menjadi masyarakat yang berbasis kebudayaan, yaitu kebudayaan Islam. kemajuan kebudayaan sosial ini tergantung pada tingkat kebudayaan kesatuan sosialnya. Inilah fungsi sosial masjid.

\section{c. Politik}

Fungsi masjid dalam perspektif politik sebenarnya sudah berlangsung sejak masa nabi di Madinah hingga sekarang. Masjid adalah tempat berkumpulnya umat Islam secara menyeluruh tanpa perbedaan-perbedaan. Masjid memang tempat yang sangat strategis bagi kegiatan kegiatan sosial, terutama politik dan ekonomi disamping kegiatan utamanya sebagai tempat ibadah Sholat. Hal tersebut tentunya bukan sesuatu yang aneh, sebab pada masa Nabi pun masjid menjadi pusat kegiatan politik. Bahkan sebagai basis militer dan pusat komando. ${ }^{19}$

Fungsi masjid sebagai arena perjuangan politik yang identik dengan kekuasaan sebagaimana dicontohkan Nabi tentu saja berbeda dengan anggapan masjid sebagai tempat kampaye partai politik. Hal ini memiliki makna bahwa seluruh umat Islam yang aktif dalam berbagai partai memiliki kesempatan yang sama terhadap penggunaan masjid. Hubungan masjid dengan kegiatan politik umat bukan hanya sebatas hubungan resip rokal, namun umat Islam semestinya berusaha untuk memakmurkan masjid. Masjid adalah simbol persatuan umat sementara hubungan umat dengan politik juga mendapat Isyarat dan tempat dalam Islam. ${ }^{20}$

\footnotetext{
Masjid, hal.53

${ }^{18}$ H. Mahmud Hamundu, Pedoman Menejemen Organisasi Jamaah

${ }^{19}$ A. Bachrun Rifa'i dan Moch. Fakhruroji, Menejemen Masjid, hal. 54

${ }^{20} \mathrm{Ibid}$, . Hal 56
} 


\section{d. Pendidikan}

Masjid adalah pusat pendidikan dan pengajaran dan karenanya masjid juga disebut sebagai pusat ilmu. Ilmu-ilmu disampaikan melalui pengkajian-pengkajian, ceramah kuliah dan khutbah. Ketika dimasjid, Nabi sering mendiskusikan persoalan-persoalan keyakinan dan norma perilaku. Dalam hal ini, Gazalba memiliki pandangan bahwa pelajaran pertama yang langsung berhubungan dengan masjid adalah Al-Qur'an dan Hadits. Pangkal pengajaran Islam adalah menghapal dan mengartikan Al-Qur'an. sesudah itu kemudian pelajaran Hadits yang mengatur perilaku perbuatan Muslim. ${ }^{21}$

Mohammad Natsir dalam buku Fiqhud Da'wah mengatakan bahwa masjid merupakan lembaga risalah, tempat mencetak umat yang beriman, beribadah menghubungkan jiwanya dengan khaliq, umat yang beramal shaleh dalam kehidupan masyarakat, umat yang berwatak dan berakhlak teguh. ${ }^{22}$

Rasulullah membina dan mendidik para sahabat di dalam masjid. Tradisi ini dilanjutkan oleh para Tabi' in dan Tabi'ut Tabi'in. Maka selayaknya di era modern ini masjid mampu menjadi pusat ilmu dan pusat da'wah islamiyah. Keberadaannya dalam rangka meningkatkan dan menumbuhkan wawasan serta pengetahuan keislaman sebagai wujud kepedulian dan sekaligus menegakkan nilai-nilai keislaman di tengah masyarakat. ${ }^{23}$

\section{e. Ekonomi}

Menurut Gazalba hubungan antara peranan masjid dengan ekonomi bukan hubungan dalam wujud tindakan riil ekonomi seperti kegiatan produksi, distribusi dan konsumsi. Peranannya

${ }^{21}$ A. Bachrun Rifa'i dan Moch. Fakhruroji, Menejemen Masjid, hal 59

${ }^{22}$ M. Natsir, Fiqhud Da'wah, Jakarta: Yayasan Capita Selecta dan Media Da'wah, 2008, hal. 5

${ }^{23}$ Bidang Pemberdayaan Daerah \& Kerjasama Dalam Negri Dewan

Da'wah Islamiyah Indonesia, Panduan Pengelolaan Masjid \& Islamic Centre, hal. 22 
terletak pada bidang ideal atau konsep ekonomi yang pangkal dan asasnya adalah Al-Qur'an dan Hadits.

Ide-ide dasar prinsip Islam mengenai ekonomi berlaku dan dipraktekan oleh umat Islam dari dulu hingga kini. Masjid tetap memainkan dalam kehidupan modern. Dahulu masjid secara induktif kemudian melahirkan kompleks pertokoan. Maka pada zaman sekarang dimana ada pertokoan disitu ada masjid. Karena toko-toko tersebut sekaligus dapat membantu segala perlengkapan masjid dan sarananya. ${ }^{24}$

Kegiatan perekonomian sangat penting bagi umat Islam untuk menunjang kehidupan. Bahkan dapat dipastikan bahwa ekonomi merupakan tulang punggung dalam perjuangan menyebarnya Islam.

\section{f. Pengembangan Seni-Budaya}

Fungsi masjid sebagai fungsi pengembangan seni dan budaya, terutama seni arsitektur. Bahkan lebih spesifik bahwa masjid merupakan simbol seni budaya Islam. Sebagai contoh Masjid Haram di Mekah dan Masjid Nabawi di Madinah dan di beberapa Negara muslim nilai seni arsitektur khususnya lebih beragam dan berfariasi seperti Masjid Amir Ibn Ash di Pustat Mesir, masjid al aqso di jerussalem, masjid jami' al Walid di Damaskus dan masjid Abdurrahman di cordova spanyol boleh disebut sebagai masjidmasjid yang memiliki cita rasa seni yang tinggi dan memikat.

Berbicara mengenai seni, seni adalah semua yang menimbulkan keharuan keindahan dan semua yang diciptakan untuk melahirkan rencana itu. Bahkan Shihab mengatakan bahwa seni merupakan ekspresi ruh dan budaya manusia yang mengandung dan mengungkapkan keindahan. ${ }^{25}$

Tidak semua keindahan atau seni dapat ditolerir oleh Islam seni atau keindahan itu terlarang ${ }^{26}$ apabila mengandung unsur-unsur:

\footnotetext{
${ }^{24}$ A. Bachrun Rifa'i dan Moch. Fakhruroji, Menejemen Masjid, hal 65

${ }^{25}$ A. Bachrun Rifa'I dan Moch. Fakhruroji, Menejemen Masjid, hal. 69

${ }^{26}$ Ibid., hal. 72
} 
dapat merusak agama, merusak jiwa, merusak kehormatan, merusak harta benda dan merusak keturunan.

Masjid dalam fungsinya sebagai sarana pengembangan sani dan budaya lebih berhubungan dengan faktor etika Islam itu sendiri. Seni arabesk dan kaligrafi Arab merupakan salah satu ekspresi keindahan yang hingga kini dapat ditemui di masjid-masjid bersejarah. Dalam fungsinya inilah, masjid memiliki peran sebagai simbol peradaban yang menyisakan beberapa bukti sejarah melaui ekspresi kesenian dan kebudayaan masyarakat Islam dimasa lalu. Fungsi seni dan budaya ini harus tetap dilestarikan dengan cara memberikan pemahaman secara menyeluruh akan manfaat seni dan budaya bagi pengembangan masjid. ${ }^{27}$

\section{Pembagian Nilai-nilai Keislaman}

\section{a. Akidah}

Akidah secara etimologi berasal dari 'aqd yang berarti pengikatan. Akidah adalah apa yang diyakini oleh seseorang. Akidah merupalan perbuatan hati, yaitu kepercayaan hati dan pembenarannya kepada sesuatu $^{28}$

Secara syara' akidah yaitu iman kepada Allah, para MalaikatNya, Kitab-kitabNya, para RasulNya dan kepada Hari Akhir serta kepada qadar yang baik maupun yang buruk. Hal ini disebut juga sebagai rukun iman. $^{29}$

Akidah berfungsi sebagai landasan hidup seorang muslim. Sebagai landasan hidup dengan sendirinya akan membentuk sikap hidup penganut-pengutnya sesuai dengan ajaran Islam ${ }^{30}$

b. Syari'ah

${ }^{27}$ Ibid., 73

${ }^{28}$ Shalih bin Fauzan bin Abdullah al-Fauzan, Kitab Tauhid 1, Jakarta: Darul Haq, 2012, Cet XXI, hal. 3

${ }^{29}$ Ibid., hal. 3

${ }^{30}$ H.M. Nasution, Islam dan Problema-problema Masyarakat, hal. 5 
Syari'ah secara etimologi berarti 'jalan'. Syariat Islam adalah satu sistem norma Ilabi yang mengatur hubungan antara manusia dan Tuhan, hubungan sesama manusia, serta hubungan antara manusia dan alamnya. ${ }^{31}$

Menurut istilah para ulama, syari'ah adalah; "Hukum-hukum yang ditetapkan oleh Allah untuk hamba-hambaNya yang dibawa oleh salah seorang NabiNya, baik hukum-hukum tersebut berhubungan dengan cara-cara bertingkah laku, yaitu yang disebut dengan hukum-hukum cabang (furu) ${ }^{\text {"32 }}$

Imam Akbar Mahmud Syaltut mendefinisikan Syari'ah dikutip dari Djazuli dalam buku Ilmu Fiqh. Syariah adalah:

"pengaturan-pengaturan yang digariskan Allah atau pokok-pokoknya digariskan Allah agar manusia berpegang kepadanya, di dalam hubungan manusia dengan Tubannya, manusia dengan saudaranya sesama muslim, dengan alam dan di dalam bubungannya dengan kehidupan."${ }^{, 33}$

Dapat disimpulkan bahwa kaidah Syariat secara garis besar terbagi atas dua bagian ${ }^{34}$ :

\section{Kaidah ibadah}

Dalam arti khusus (Kaidah Ubudiyah), yaitu tataaturan Ilahi yang mengatur hubungan ritual langsung antara hamba dan Tuhannya yang acara, tatacara, serta upacaranya telah ditentukan secara terinci dalam Al-Qur'an dan Sunnah Rasul. Pemahaman mengenai ibadah dalam arti khusus ini mencakup thaharah (bersuci), shalat, zakat, puasa dan haji.

Ibadah adalah perkara tauqifiyah yaitu tidak ada suatu bentuk ibadah yang disyariatkan kecuali berdasarkan Al-Qur'an dan AsSunnah. Agar ibadah dapat diterima ibadah disyaratkan harus

\footnotetext{
${ }^{31}$ H.Endang Saifuddin Anshari, Wawasan Islam, 2004, hal. 44

${ }^{32}$ Djazuli, Ilmu Fiqh, Jakarta: Kencana Prenada Media Group, 2010, Cet 7, hal. 2

${ }^{33}$ Djazuli, Ilmu Fiqh, Jakarta: Kencana Prenada Media Group, 2010, Cet 7, hal. 2

${ }^{34}$ H.Endang Saifuddin Anshari, M.A, Wawasan Islam, 2004, hal. 45
} 
benar. Syarat pertama adalah ikhlas karena Allah semata, bebas dari syirik. Dan syarat kedua adalah Ittiba', sesuai dengan tuntutan Rasulullah. ${ }^{35}$

\section{Kaidah Muamalah}

Agama memberikan peraturan yang sebaik-baiknya, karena dengan teraturnya muamalat, maka penghidupan manusia jadi terjamin pula dengan sebaik-baiknya sehingga perbantahan dan dendam tidak akan pernah terjadi. ${ }^{36}$

Muamalah dalam arti luas yaitu tata aturan Ilabi yang mengatur hubungan sesama manusia dan hubungan antara manusia dan benda.

\section{c. Akhlak}

Dikutip dari buku Etika Dakwah secara etimologi akhlak menurut Al-Munawir diartikan sebagai tabi'at, karakter, perangai, watak yaitu sifat yang telah tertanam dengan kuat atau mendarah daging pada diri seseorang lantaran faktor pendidikan, pembiasaan, pembinaan, pelatihan yang pernah ditekuni. ${ }^{37}$

Dalam buku Wawasan Islam, akhlak berarti 'perbuatan' ada sangkut pautnya dengan kata Khalik 'pencipta', dan 'makhluk' yang diciptakan. Secara garis besar akhlak Islam mencakup beberapa hal diantaranya adalah akhlak manusia terhadap khalik, akhlak manusia terhadap makhluk, makhluk bukan manusia sepert flora, fauna dan lain-lain. Dan makhluk manusia yaitu diri pribadi, rumah tangga, keluarga, antartetangga dan masyarakat. ${ }^{38}$

${ }^{35}$ Yazid bin Abdul Qadir Jawas, Prinsip Dasar Islam, Bogor: Pustaka Attaqwa, 2010, cet. 8 , hal. 107

${ }^{36}$ Sulaiman Rasjid, fiqh Islam, Bandung: Sinar Baru Algensindo, 2013, Cet 63, hal. 278

${ }^{37}$ Enjang AS dan Hajir, Etika Dakwah,Bandung: Widya Padjajaran, 2009, hal. 133

${ }^{38}$ H.Endang Saifuddin Anshari, M.A, Wawasan Islam, 2004, hal. 46 
Menurut Muhammad Nur Abdul Hafizh Suwaid yang dimaksud dengan akhlak (Al-Khuluq) adalah (As-Sajiyyah) dan tabi'at (at-thab). Demikian seperti yang disebutkan dalam kamus As-Shahih. Qurtubi dalam tafsirnya mengatakan, "kata Al-Khuluq menurut bahasa adalah suatu yang menjadi kebiasaan seseorang yang berupa adab. Sebab, ia menjadi seperti pembawaan (alKhilaqab) yang ada pada dirinya. Adapun adab yang menjadi tabiatnya disebut Al-Khim (watak) yang berarti As-Sajiyyah (perangai) dan tabiat. Dengan demikian yang disebut Al-Khuluq (akhlak) itu adalah tabiat yang bisa dibentuk sedangkan Al-Khim adalah tabiat yang bersifat naluri." ${ }^{39}$

Dalam penelitian ini digunakan penelitian lapangan (field reseach) dengan metode penelitian deskriptif kualitatif. Yaitu studi mengenai penelitian dengan menghimpun data, mengelola dan menganalisis secara deskriptif dengan menafsirkan secara kulitatif. Penelitian berupa mendeskripsikan mengenai Peranan Masjid Jamik Al-Hidayah Batumarta Dalam Menanamkan Nilai-Nilai Keislaman di Desa Martajaya dengan cara observasi, wawancara, dokumentasi yang kemudian diuraikan dalam bentuk tulisan.

Teknik pengumpulan data merupakan tahap yang paling utama dalam penelitian. Karena tujuan dari penelitian adalah mendapatkan data. Teknik pengumpulan data dalam penelitian ini dilakukan dengan observasi (pengamatan), interview (wawancara) dan dokumentasi.

\section{Teknik Analisis Data}

Analisa yang digunakan dalam penelitian ini adalah analisa model Miles dan Huberman mereka mengungkapkan bahwa aktivitas dalam analisis data kualitatif dilakukan secara interaktif dan berlangsung secara terus menerus sampai tuntas, sehingga datanya jenuh. Aktivitas dalam analisis data ini dibagi menjadi tiga:

${ }^{39}$ Muhammad Nur Abdul Hafizh Suwaid, Mendidik Anak Bersama Nabi, Surakarta: Pustaka Arafah, 2017, Cet. X, hal. 222 


\section{Data Reduction (reduksi data)}

Mereduksi data yaitu merangkum data seperti hasil catatan yang telah diperoleh dari lapangan yang jumlahnya cukup banyak. memilih hal-hal pokok dan menfokuskan pada hal-hal yang penting. Dengan demikian akan memberikan gambaran yang lebih jelas dan mempermudah peneliti untuk melakukan pengumpulan data selanjutnya.

2. Data Display (penyajian data)

Dalam penelitian kualitatif penyajian data bisa dilakukan dalam bentuk uraian singkat. Miles dan Huberman mengatakan yang sering digunakan untuk menyajikan data dalam penelitian kualitatif adalah dengan teks yang bersifat naratif.

3. Conclusing Drawing (Verification)

Langkah ketiga adalah pemeriksaan kesimpulan dan verifikasi. Verifikasi dapat dilakukan secara singkat, yaitu dengan mengumpulakn data baru. Dari berbagai sumber data yang telah diperoleh seperti data wawancara, observasi, dan dokumentasi.

\section{HASIL PENELITIAN DAN DISKUSI}

Masjid Jamik Al-Hidayah Batumarta terletak di Dusun Trimulyo Desa Martajaya Kecamatan Lubukraja Kabupaten Ogan Komering Ulu Sumatera Selatan. Dibangun atas program transmigrasi pada tahun 1978. Terletak dipusat desa tidak jauh dari Pasar Gotong Royong.

Desa Martajaya adalah salah satu desa di kawasan ex Transmigrasi Batumarta. Nama batumarta itu sendiri merupakan singkatan Baturaja dan Martapura karena letak Batumarta persis ditengah-tengah antara Baturaja dan Martapura.

Proyek Transmigrasi Batumarta dahulu dikelola oleh pemerintah Departemen Transmigrasi (Depnaker Trans) pada tahun 1976, dibuka dalam dua tahap. Tahap pertama dibuka sebelas unit atau desa. Yaitu unit I sampai dengan unit XI. Tahap kedua dilanjutkan dengan unit XII sampai dengan Unit XVI. Desa Martajaya merupakan pemekaran desa dari Desa Batumarta II yang dipecah menjadi tiga desa yaitu Desa Baturaden, Desa 
Batumarta II dan Desa Martajaya. Desa Martajaya dibuka atau awal penetapan Transmigrasi pada tahun $1978 .{ }^{40}$

Masjid merupakan salah satu sarana ibadah yang dibangun atas program transmigrasi disetiap unit atau desa Transmigrasi Batumarta. Mulai dari unit I sampai dengan unit XVI. Pada saat itu pimpinan proyek transmigrasinya bernama Bapak Sukirmo.

Pada saat awal berdirinya Masjid Jamik Al-Hidayah, ada beberapa tokoh yang berperan aktif dalam sejarah berdirinya dan berkembangan Masjid Jamik Alhidayah Batumarta. Diantaranya adalah: Bapak Zuhdi Safari beliau transmigran asal Boyolali yang pada saat itu menjabat sebagai Kepala Sekolah Dasar. Bapak Mansur Suryadi beliau transmigran asal Ngawi Jawa Timur yang aktif berda'wah di Batumarta. Bapak Hidayat Firmansyah beliau Petugas Penyuluh Lapangan (PPL) Pertanian. Bapak Sambito Slamet beliau kepala Desa Batumarta II pertama dan Bapak Amirillah beliau Kepala Dusun Pasar Gotong Royong

Bapak Zuhdi Safari dan bapak Mansur Suryadi bertugas sebagai Imam sekaligus khotib pertama di Masjid Jamik Al-Hidayah Batumrta dan sebagai ta'mir masjid pertama yang mengatur perjadwalan petugas shalat jum'at seperti imam, khotib dan muadzin.

Menurut Bapak Ahmad Romadlon, Jamaah shalat jum'at Masjid Jamik Al-Hidayah Batumarta merupakan jamaah terbanyak dibandingkan dengan masjid-masjid lain yang ada di Batumarta hal tersebut dikarenakan Masjid Jamik Al-hidayah Batumarta terletak di central proyek transmigrasi sehingga selain jamaahnya adalah masyarakat transmigran juga ada karyawan-karyawan transmigrasi, guru-guru SD, SMP, SMA dan karyawan lainnya ${ }^{41}$.

Masjid Jamik Al-Hidayah Batumarta terletak disebelah puasat perbelanjaan Pasar Gotong Royong yang beroprasi setiap hari senin dan

${ }^{40}$ Ahmad Romadlon, Pembina Takmir Masjid Jamik Al-Hidayah Batumarta, Wawancara, Batumarta 1, 8 Maret 2019

${ }^{41}$ Ahmad Romadlon, Pembina Takmir Masjid Jamik Al-Hidayah Batumarta, Wawancara, Batumarta 1, 8 Maret 2019 
jum'at. Sehingga tidak sedikit jamaah yang hadir dari berbagai macam daerah.

Penamaan masjid pada mulanya hanya Masjid Al-Hidayah kemudian pada tahun 2015 masjid ini ditetapkan sebagai masjid kecamatan sehingga ditambah menjadi Masjid Jamik Al-Hidayah Batumarta. Meskipun sudah ada pemecahan desa, namun diharapkan dengan adanya nama Batumarta warga atau generasi seterusnya tidak melupakan sejarah bahwa berdirinya masjid ini adalah dari proyek transmigrasi Batumarta ${ }^{42}$. Maka jadilah nama Masjid Jamik Al-Hidayah Batumarta. Pengurus Masjid Jamik Al-Hidayah Batumarta dari masa kemasa, Bapak Mansur Suryadi Tahun 1978-1984, Bapak Ahmad Romadhon Tahun 1985-1992, Bapak Istad Tahun 1993-2006, Bapak Yusri Hamid Tahun 2007 hingga saat ini (tahun 2019).

\section{Visi dan Misi Masjid Jamik Al-Hidayah Batumarta Visi}

Visi dari Masjid Jamik Al-Hidayah Batumarta ini adalah menjadi masjid yang mandiri sebagai wadah pembinaan umat muslim, pengembangan dan pembangunan masyarakat Islami.

\section{Misi}

a. Menyelenggarakan dan menyediakan tempat peribadatan bagi umat Islam secara benar, aman dan nyaman

b. Menyelenggarakan dan menyediakan tempat untuk melaksanakan pengajian/pendidikan dan perayaan hari besar Islam guna memberikan pencerahan dan peningkat kesadaran beragama dan bermasyarakat

c. Menjadikan Masjid Jamik Al-Hidayah Batumarta sebagai pusat penerimaan, pengelolaan dan pendistribusian sunber daya zakat, infak dan shadaqah berlandaskan kebenaran dan kemaslahatan untuk membebaskan masyarakat dari kebodohan dan kemiskinan

\footnotetext{
42 Yusri Hamid, Ketua Takmir Masjid Jamik Al-Hidayah Batumarta, Wawancara, Martajaya, 11 maret 2019
} 
d. Mengelola dan mengembangkan sarana dan prasarana yang mendukung tujuan tersebut.

\section{Aktifitas Masjid Jamik Al-Hidayah Dalam Menanamkan Nilai-nilai Keislaman di Desa Martajaya}

Untuk mengetahui pranan Masjid Jamik Al-Hidayah Batumarta Dalam Menanamkan Nilai-Nilai Keislaman di Desa Martajaya, perlu kami uraikan secara singkat aktivitas masjid ditengah-tengah masyarakat, yaitu sebagai berikut :

\section{Kegiatan dalam aspek akidah}

a. Kajian rutin kitab tauhid

Kajian ini diadakan setiap hari senin malam selasa $b a^{\prime} d a$ magrib hingga isya'. Kajian ini dibuka untuk umum. Metode penyampaian materi ini dengan cara ceramah. Materi yang disampaikan kepada jamaah adalah tauhid dasar yang diambil dari kitab tauhid karangan DR. Sholih Fauzan bin Fauzan. Pada awal pembahasan akidah, pemateri menekankan mengenai pentingnya penguatan akidah dan pentingnya mempelajari akidah. mengingat bahwa akidah merupakan pondasi awal seorang muslim.

Kajian akidah rutin ini bertujuan untuk mengokohkan akidah umat supaya tidak goyah dan tidak mudah terpecah belah hanya karena masalah sepele. Langkah yang dilakukan untuk mengokohkan akidah para jamaah yaitu mencerehkan umat dari dua sisi. Yang pertama adalah dari sisi tafsiyah dengan melakukan pemurnian akidah kemudian ibadah dan amalanamalan. Dan yang kedua mencerahkan dari sisi rabbaniyah. ini merupakan langkah panjang dan target panjang hingga tercipta masyarakat yang terbina. Sehingga tidak lagi menjadi jamaah yang rapuh mudah terpecah belahkan. ${ }^{43}$

b. Khutbah Jum'at

Sholat Jum'at adalah sholat jama'ah yang diwajibkan atas setiap laki-laki dewasa muslim. Hal yang menarik dari ibadah sholat Jum'at adalah adanya khutbah Jum'at yang disampaikan oleh khotib sebelum dilaksanakannya

Maret 2019

${ }^{43}$ Nur 'Ilmi, Pemateri Kajian Rutin Tauhid, Wawancara, Martajaya, 18 
sholat jum'at. Khutbah Jum'at merupakan salah satu media yang strategis untuk menyampaikan da'wah Islam. salah satunya adalah materi akidah. Inilah salah satu strategi yang digunakan oleh Masjid Jamik Al-Hidayah dengan memanfaatkan khutbah jum'at sebagai upaya menanamkan nilainilai keislaman pada masyarakat Martajaya.

c. Ma'had Tahfidz Manarul Hidayah dan Tahlila

Ma'had Tahfiz Manarul Hidayah merupakan program tahfidz bagi anak-anak usia sekolah. Kegiatan ini dimulai pukul 13.30 sampai dengan sholat ashar. Dengan sistem mengaii dan menghafal dibimbing dan disimak langsung oleh ustadz dan ustadzah yang didatangkan dari Ma'had Tahfidz Isykarima Surakarta.

Kemudian program mengenalkan Qur'an bagi anak usia dini maka, dibangunlah sekolah setara dengan TK yaitu Tahlila (Tahfidzul Qur'an lil Auladinaa). Sekolah yang berbasis menghafal Al-Qur'an. namun pada proses belajarnya anak-anak tidak hanya diajak untuk menghafal. Akan tetapi ada pula materi akidah, ibadah dan akhlak yang disampaikan. ${ }^{44}$

Anak-anak menjadi target penanaman akidah. Karena mereka kelak akan menghadapi tantangan globalisasi dan teknologi hal itu membutuhkan kesiapan pemahaman Islam yang benar. Oleh karena itu dengan adanya Tahfidz dan juga Tahlila diharapkan Masjid Jamik Al-Hidayah Batumarta mencoba mengambil peran untuk memberikan warna dalam kehidupan sehari-hari pada anak-anak. ${ }^{45}$

\section{Kegiatan Dalam Aspek syariah}

Ibadah mencakup dua hal yaitu hubungan antara hamba dan Allah (Habluminallah) dan hubungan antara manusia dengan sesama. Maka Masjid Jamik Al-Hidayah Batumarta memiliki kegiatan diantaranya adalah:

a. Sholat berjamaah

Kegiatan sholat fardu secara berjama'ah secara rutin telah terselenggara. Salah satu program yang dimiliki oleh Masjid Jamik AlHidayah Batumarta adalah pada hari jum'at diwaktu sholat subuh imam

Mei 2019

${ }^{44}$ Amanati Sholihah, kepala sekolah Tahlila, Wawancara, Martajaya, 22

${ }^{45}$ Yusri Hamid, Ketua Takmir Masjid Jamik Al-Hidayah Batumarta, Wawancara, Martajaya, 11 Maret 2019 
selalu membaca ayat Sajadah. Sedangkan kegiatan pekanan seperti sholat jum'at, jamaah masjid Jamik Al-Hidayah Batumarta relatif lebih banyak dibandingkan dengan masjid-masjid lain yang berada di Batumara. Hal ini diketahui dari banyaknya perolehan hasil kotak amal. $^{46}$

Masjid Jamik Al-Hidayah Batumarta memiliki cara untuk menarik masyarakat agar mau solat berjamaah dimasjid. Salah satunya dengan membuat baliho yang berisi sindiran atau ajakan yang dipasang di halaman dan pagar masjid. Beliho tersebut bertuliskan "Langkah terberat laki-laki muslim adalah menuju masjid".

Dibulan ramadhan, Masjid Jamik Al-Hidayah Batumarta memiliki sebuah program rutin tahunan dengan melaksanakan shalat tarawih dua sesi. Sesi pertama dimulai ba'da isya' dengan bacaan surat-surat pendek. Sesi kedua dimulai pukul 01.30 wib dengan program satu malam satu juz.

b. Santunan kaum dhuafa'

Sebuah program sosial kemasyarakatan yang diadakan oleh masjid dengan memberikan paket sembako kepada kaum dhu'afa, data-data warga yang membutuhkan bantuan tersebut didapat dari ketua RT atau Kadus. Pendanaan kegiatan ini diambil dari dana sosial masjid yaitu $25 \%$ dari uang masuk melalui infaq jum'at dan harian ${ }^{47}$.

Dalam satu bulan, masjid membagikan 20 buah paket sembako bagi kaum dhu'afa dengan nilai 150.000 ribu rupiah per paket sembako. Paket sembako tersebut dibagikan tidak hanya kepada warga Desa Martajaya saja akan tetapi kepada warga desa lain yang membutuhkan.

Selain memberikan paket sembako, masjid juga memberikan santunan kepada jamaah yang sakit. Ini merupakan sebuah program kegiatan yang bersifat insidental.

Tujuan dari kegiatan tersebut adalah agar menarik para mukhsinin agar turut srta berbagi kepada sesama melalui pengelolaan Masjid Jamik Al-Hidayah Batumarta. Maka dana infak masjid tidak dipergunakan

\footnotetext{
${ }^{46}$ Yusri Hamid, Ketua Takmir Masjid Jamik Al-Hidayah Batumarta, Wawancara, Martajaya

${ }^{47}$ Ibid,.
} 
untuk pembangunan tetapi dipergunakan untuk dana sosial seperti yang telah disebutkan diatas.

c. Tabungan qurban

Sebuah program untuk memfasilitasi jamaah yang hendak berqurban secara jama'i kemudian dikelola oleh masjid. Aturan tabungan ini dengan mewajibkan jamaah untuk menyetorkan sejumlah uang setiap bulan melalui petugas pengepul selama 10 bulan untuk kemudian dibelikan hewan qurban berupa sapi.

Masjid sebagai syiar agama sudah seharusnya mengadakan qurban setiap tahunnya. Maka dengan adanya tabungan qurban, hampir setiap tahun masjid dapat memotong hewan kurban berupa sapi sebanyak tujuh ekor kemudain dagingnya dibagikan kepada masyarakat. hal itu sangat memberi manfaat setidaknya bagi mereka yang tidak pernah makan daging, pada hari itu dapat berbahagia karna mendapat daging qurban.

d. Kajian rutin bulanan fiqh wanita

Kajian ini khusus untuk wanita dan pematerinya pun wanita. Dengan menggunakan metode diskusi, kajian ini dikelola sedemikian rupa dengan materi dimulai dari bab thaharah hingga kajian mengenai fiqh-fiqh konteporer.

Ibu merupakan madrasatul ula bagi anak-anaknya, maka dari itu seorang ibu tidak boleh berhenti belajar supaya dapat mendampingi anak-anaknya dalam mengajarkan agama Islam. Mengingat pada saat ini, maraknya penggunaan sosial media disemua kalanganan telah merubah kehidupan masyarakat baik dari segi berpakaian, pergaulan dan gaya hidup. tidak hanya anak muda ternyata ibu-ibu juga menjadi salah satu korbannya. Menurut Ketua Takmir Masjid Jamik Al-Hidayah Batumarta, diharapkan dengan adanya kajian rutin ini para ibu-ibu menjadi bijak menghadapi perkembangan teknologi saat ini. ${ }^{48}$

e. Kajian rutin kitab Hisnul Muslim

Kajian ini diadakan pada hari selasa pekan ke dua dan ke empat. Dimulai ba'da magrib hingga isya'. Selain Kajian mengenai do'a-do'a

\footnotetext{
${ }^{48}$ Yusri Hamid, Ketua Takmir Masjid Jamik Al-Hidayah Batumarta, Wawancara, Martajaya, 11 Maret 2019
} 
harian dan dzikir yang sesuai dengan ajaran Nabi Muhammad Shalallabu 'alaibiwassalam,materi yang disampaikan pada kajian ini juga mengenai ibadah sehari-hari seperti Sholat.

Dengan menggunakan metode ceramah. Pada penjelasan materi mengenai wudhu, pemateri memperaktikkan langsung tata cara wudhu yang benar. Kemudian mempersilahkan salah satu jamaah untuk memperaktikkan ulang. Sehingga para jamaah bisa paham bukan hanya dari segi teori.

f. Kegiatan dalam aspek akhlak

Masjid Jamik Al-Hidayah Batumarta dalam kajian rutin ba'da magrib memiliki salah satu materi mengenai akhlak sehari-hari yaitu melalui materi riyadussalibin. Maka dalam kajian riyaudussalibin pemateri menyampaikan prihal bab sabar, ikhlas, menginfakkan harta, berjuang dijalan Allah, mencintai tetangga dan lain sebagainya. Diharapakn dari kajian tersebut Masyarakat dapat menerapkan dalam kehidupan seharihari. ${ }^{49}$

Kajian ini menggunakan metode ceramah kemudian diakhir penyampaian materi, pemateri mempersilahkan peserta kajian untuk bertanya. Menurut Ustadz Imam Sugiarto selaku pemateri kajian banyak sekali pertanyaan yang diajuka ini menunjukkan antusis para jamaah dalam mendengarkan materi yang disampaikan.

\section{Analisis Peranan Masjid Jamik Al-Hidayah Batumarta Dalam Menanamkan Nilai-Nilai Keisalaman di Desa Martajaya}

Berdasarkan penelitian di atas, dengan menggunakan teori Biddle dan Thomas dapat peneliti menemukan bahwa peranan Masjid Jamik AlHidayah Batumarta Dalam Menanamkan Nilai-nilai Keislaman adalah sebagai berikut:

1. Harapan tentang peranan (Expectation)

Seperti yang sudah dijelaskan bahwa harapan tentang peranan adalah harapan-harapan orang lain tentang prilaku yang seyogyanya Maret 2019

\footnotetext{
${ }^{49}$ Imam Sugiarto, Pemateri Kajian, Wawancara, Blok H Martajaya, 18
} 
ditunjukkan oleh seorang yang mempunyai peran tertentu dalam hal ini yang memegang peran adalah Masjid Jamik Al-Hidayah Batumarta. Masjid memiliki peranan dalam proses penanaman nilai-nilai keislaman bukan hanya sebagai tempat ibadah. Dari hasil wawancara yang penulis lakukan bahwa masyarakat mengharapkan masjid lebih memberikan ruang khusus untuk para remaja. Seperti kajian khusus remaja wanita, atau kegiatan yang menambah semangat para remaja dalam mempelajari Islam. Melihat kurangnya minat para remaja untuk turut dalam kegiatan masjid. Baik itu sholat berjamaah atau kajian. ${ }^{50}$

Melihat jumlah santri Ma'had Tahfidzul Qur'an yang mencapai 195 anak, ini menjadi salah satu bukti bahwa para orang tua mengharapkan anak-anaknya bisa mendapatkan bekal dalam menghafal Al-Qur'an. menurut salah seorang pengajar ma'had tahfiz mengatakan bahwa adanya ma'had tahfiz ini, berpengaruh pada kehidupan masyarakat martajaya. Diantaranya adalah merubah pandangan para orang tua tentang dunia pendidikan. Jika dulu orang tua lebih mendorong anak-anaknya untuk mengejar pendidikan yang bersifat duniawi, saat ini para orang tua mulai berubah orentasinya bukan lagi perkara dunia melainkan tentang akhirat. Bahkan orang tua berani membayar mahal untuk biaya sekolah anak-anak mereka dipesantren yang berbasis menghafal al-Qur'an. ${ }^{51}$ Bahkan saat ini masjid menambah program menghafal untuk ibu-ibu rata-rata pesertanya adalah para wali santri Ma'had Tahfidz Manarul Hidayah. Terselenggaranya program ini dikarenakan para orang tua merasa termotivasi karena anak-anak mereka kerap kali menghafal dan mengulang hafalan dirumah. ${ }^{52}$

Kemudian diranah pendidikan anak-anak usia dini, menurut Ustazah Sholihah selaku kepala sekolah yang telah mewawancara para wali murid yang mengaku bahwa mereka sangat berharap dengan memasukkan anak mereka ke sekolah tahlila, anak mereka menjadi hafidz qur'an dan memiliki bekal agama yang cukup dari segi akidah,

Juli 2019

${ }^{50}$ Aisya Adila, Jamaah Kajian Rutin, Wawancara, Blok H Martajaya, 5

${ }^{51}$ Leyga Aini Prima Madusari, Pengajar Tahfidz Manarul Hidayah,

Wawancara, Martajaya, 14 Juni 2019

52 Ibid 
syariah dan akhlak. ${ }^{53}$ Salah seorang calon wali murid yang penulis wawancari mengatakan selain ingin mempunyai anak yang menghafal alqur'an, beliau memilih memasukkan anaknya ke tahlilah karena menurutnya sekolah tersebut berbeda dengan sekolah yang lain seperti tidak diajarkan menyanyi-nyanyi, para gurunya yang berbusana syar'i bahkan ada yang berniqab, dan terlihat pula ketika disekolah guru-guru selalu memberikan contoh langsung kepada para murid. ${ }^{54}$

Dari apa yang disampaikan oleh ibu tersebut dapat diambil kesimpulan bahwa adanya sebuah harapan dari masyarakat kepada tahlila agar dapat memberikan pelajaran dan bekal kepada anaknya mengenai agama islam agar anaknya memiliki bekal dikemudian hari. Hal ini senada dengan apa yang dimaksudkan oleh Biddle dan Thomas bahawasanya ada harapan dari orang lain dalam hal ini adalah masyarakat kepada pemegang peran yaitu masjid, yang seyogianya ada pada pemegang peran. Bahwa sebuah masjid selain menjadi tempat untuk beribadah juga dapat menjadi sarana pendidikan bagi anak-anak atau semua kalangan.

2. Wujud prilaku (Performance)

Sebagaimana yang telah penulis sampaikan pada bab dua, bahwa dalam peranan ada yang disebut dengan wujud prilaku. Wujud prilaku ini adalah sebuah aksi dari seorang aktor dalam memainkan perannya. Dalam hal ini yang menjadi aktor adalah Masjid Jamik Al-Hidayah Batumarta. Masjid menjalankan perannya sebagai sarana menanamkan nilai-nilai keislaman pada masyarakat melalui program-program yang direncanakan.

Dalam menjalankan peranannya untuk menanamkan nilai-nilai keislaman kepada masyarakat di Desa Martajaya, Masjid Jamik AlHidayah Batumarta memiliki beberapa cara. Cara tersebut hanya akan terwujud jika didahului dengan penyampaian ilmu-ilmu agama Islam yang bersumber dari Al-Qur'an dan Assunnah maka Masjid Jamik AlHidayah Batumarta menyelenggarakan program seperti solat

\footnotetext{
${ }^{53}$ Amanati Sholihah, kepala sekolah Tahlila, Wawancara, Martajaya, 22 Mei 2019

${ }^{54}$ Silmy Romadhon, Calon Wali Murid Sekolah Tahlila, Wawancara, Batumarta 1, 24 Mei 219
} 
berjamaah lima waktu, kajian-kajian rutin, pendidikan anak-anak, bakti sosial dan lain sebagainya.

Pendidikan yang ditujukan untuk anak-anak yaitu dengan mendirikan Tahlila (Tabfidz, Qur'an Lil Auladina) setara dengan TK. Pendidikan yang berbasis Al-Qur'an dengan program mengenalkan Al-Qur'an kepada anak-anak usia dini. Pendirian TK ini sebagai upaya menyiapkan generasi penerus yang berjiwa qurani, jauh dari penyimpangan akidah, ibadah dan muamalah.

Tentunya pengkaderan generasi Qur'ani sejak dini sangatlah perlu di zaman sekarang, karena merekalah yang kelak akan menjadi penerus bangsa. Maka masjid Jamik Al-Hidayah Batumarta juga memiliki ma'had tahfidz yang bernama Ma'had Tahfiz Manarul Hidayah. Ma'had tahfiz ini ditujukan untuk anak-anak usia sekolah. Dari tingkat SD, SMP, dan SMA. Kegiatan ini dimulai pukul 13.30 diawali dengan murojaah bersama kemudian dilanjutkan dengan menyetorkan hafalan dengan ustad atau ustadzah hingga ashar ditutup dengan sholat ashar berjamaah dan zikir bersama. Jumlah peserta didik kurang lebih mencapai 195 anak.

Diharapakn dengan adanya TK dan Ma'had Tahfidz ini mampu mewarnai kehidupan anak-anak terlebih lagi yang tidak bisa dipungkiri lingkungan pasar ternyata membawa dampak besar bagi anak-anak terutama dari segi perkataan tidak jarang banyak anak-anak yang sering berkata kasar kepada sesama temannya, juga kemajuan teknologi yang semakin berkembang adanya warnet (Warung Internet), gadget, semakin membuat anak-anak lebih betah berlama-lama bermain game online maka diharapkan dengan menyibukkan mereka dalam menghafal Alqur'an, sehingga terjadi perubahan pada akhlak anak-anak dalam aspek pergaulan. ketika saling bertemu bukan perkara game atau sosial media yang jadi perbincangan akan tetapi tentang hafalan yang sudah dicapai.

Jika disekolah anak-anak diawasi oleh gurunya, maka dirumah sepenuhnya pelajaran yang telah diberikan disekolah diserahkan oleh orang tua masing-masing. Maka Tahlila tidak hanya ingin mengajak anak-anak untuk menghafal dan mempelajari nilai-nilai keislaman akan tetapi wali murid juga menjadi sasaran da'wah. Orang tua dibekali buku panduan untuk membimbing anak-anaknya dalam mempelajari 
materi keislaman seperti akidah, akhlak, fiqh dan tarikh. ${ }^{55}$ Dengan demikian, para orang tua turut ikut menghafal dan belajar bersama anak-anak mereka.

Pendidikan non formal ditujukan untuk masyarakat umum dengan mengadakan kajian-kajian rutuin setiap malam ba'da magrib, dengan materi seputar masalah keagamaan seperti tauhid, hisnul muslim, bulughul maram, ensiklopedi akhir zaman, sirah nabawiyah atau sababiyah dan tafsir qur'an tematik kemudian kajian mingguan untuk ibu-ibu dan tabligh akbar setiap bulannya. Dari penyelenggaraan programprogram yang telah terorganisir tersebut, masyarakat bisa langsung mengikuti. Bagi para jamaah pengajian, yang tidak paham mengenai persoalan agama, mereka dapat mengajukan pertanyaan langsung kepada pemateri atau pada persoalan akidah, pemateri mengizinkan untuk berdiskusi diluar jam kajian.

Masjid Jamik Al-Hidayah Batumarta dalam menjalankan perannya tidak terbatas hanya dengan usaha-usaha dalam pendidikan, akan tetapi ada pula kegiatan sosial, dan ekonomi. Dalam agama Islam, sebagai umat muslim kita diwajibkan untuk saling membantu antar sesama. Dalam hal ini, Masjid Jamik Al-Hidayah Batumarta dapat menjadi sarana untuk menyalurkan bantuan kepada kaum dbuafa.

Bentuk kegiatan sosial yang diadakan diantaranya adalah membagikan paket sembako kepada kaum dbuafa pada setiap bulan, secara insidental masjid juga kerap kali membatu jama'ah yang terkena musibah seperti sakit dan lain sebagainya. Hal ini sebagai upaya pendekatan kepada masyarakat agar lebih berpartisipasi dengan masjid dan ikut serta dalam kegiatan-kegiatan yang diadakan oleh masjid. Selain itu kegiatan bakti sosial ini diharapkan juga dapat menumbuhkan solidaritas serta menyadarkan para masyarakat akan pentingnya ukhuwah Islamiyah dengan ikut serta membatu sudara sesama muslim yang membutuhkan atau yang terkena musibah. Sehingga terwujudlah habluminanas yang diridhai oleh Allah.

Dalam kegiatan ekonomi, Masjid Jamik Al-Hidayah Batumarta sendiri sudah memiliki usaha dalam bentuk ril ekonomi seperti

${ }^{55}$ Amanati Sholihah, kepala sekolah Tahlila, Wawancara, Martajaya, 22

Mei 2019 
penjualan bahan bakar minyak (POM Mini), jasa penyablonan, dan barbershop atau pangkas rambut. Hal tersebut sekaligus membuka lapangan kerja bagi masyarakat terlebih lagi bagi anak-anak muda. Tujuan dari usaha-usaha tersebut agar Masjid Jamik Al-Hidayah Batumarta dapat menjadi masjid yang mandiri. Hasil pendapatan dari usaha tersebut bukan sekedar untuk pembangunan masjid akan tetapi untuk kegiatan sosial atau masjid memberikan bantuan kepada masyarakat terkhusus bagi jamaah masjid yang ingin membuka usaha dengan memimjamkan uang sebagai modal awal.

Selain memiliki peranan bagi masyarakat Martajaya, masjid Jamik Al-Hidayah Batumarta juga memiliki peran bagi para musafir sebagai tempat singgah atau istirahat. seperti visi misi dari masjid ini yaitu menyelenggarakan dan menyediakan tempat peribadatan bagi umat Islam secara benar, aman dan nyaman. Maka masjid menyediakan sarana yang nyaman seperti kamar mandi, tempat parkir yang aman. Sehingga bagi siapapun yang datang dan membawa kendaraan, masjid sudah menjamin keamanannya.

\section{Norma}

Seperti yang telah dikemukakan oleh Biddle dan Thomas norma merupakan salah satu bentuk harapan baik itu harapan yang terselubung atau harapan yang terbuka. Dalam hal ini ada dua aspek yang saling berperan yang pertama masjid, ia berperan sebagai sarana dalam menanamkan nilai-nilai keislaman kepada masyarakat, yang kedua adalah masyarakat ia berperan sebagai sasaran dari masjid yang diharapkan dapat menerapkan nilai-nilai keislaman tersebut dalam kehidupan sehari-hari. Tuntutan masjid kepada masyarakat untuk menerapkan nilai-nilai keislaman tersebut melalui proses dapat menjadi norma bagi yang memerankan.

Dari berbagai program yang sudah diselenggarakan oleh Masjid Jamik Al-Hidayah Batumarta tentu memiliki tujuan salah satunya seperti mengajak masyarakat untuk sholat berjamaah. Dari sholat berjamaah tersebut terjalinlah komunikasi antar sesama jamaah. Semakin sering sholat berjamaah maka semakin sering pula terjadi komunikasi atau paling tidak saling mengenal. Hal tersebut menambah keakraban terhadap sesama jamaah atau dalam kehidupan bermasyarakat para jamaah tersebut hidup bertangga. 
Bermula dari sholat berjamaah dalam rangka menunaikan kewajiban dari Allah Subhanabu wa Ta'ala seorang muslim dapat sekaligus memenuhi kewajibannya sebagai sesama muslim yaitu menghubungkan tali persaudaraan, saling tolong menolong maka terciptalah persatuan umat Islam dalam masyarakat. Masjid Jamik Alhidayah Batumarta telah menjalankan peranannya dalam menanamkan norma pada masyarakat mengenai akhlak dan hubungan antar sesama manusia.

Pada program lain seperti penyelenggaraan bakti sosial pembagian sembako. Diharapkan dengan adanya kegiatan ini masyarakat yang mendapatkan sembako menjadi lebih dekat dengan masjid atau menjadi jamaah tetap masjid. Meskipun pada kenyataannya hal tersebut belum sepenuhnya dapat tersealisasikan. Dan dari kegiatan ini pula masjid berharap dapat memberikan contoh sekaligus mengajak masyarakat untuk saling membantu sesama umat muslim agar tercipta rasa saling peduli, mewujudkan rasa cinta dan saling tolong menolong berbagi dengan yang membutuhkan diharapkan hal tersebut dapat menjadi suatu adat kebiasan atau norma yang terbangun di masyarkat Desa Martajaya. Pembagian sembako ini telah rutin dijalankan oleh Masjid Jamik Al-Hidayah hal tersebut berkat infak dari para mukhsinin.

Dari upaya da'wah yang dilakukan melalui kajian-kajian yang disampaikan oleh para ustadz sedikit demi sedikit telah membawa perubahan seperti pada aspek akidah. Dahulu hampir setiap tahun desa merayakan ulang tahun disertai acara memotong kambing, mengundang wayang dan hal-hal yang menjurus kepada kesyirikan. saat ini sudah tidak ada lagi acara tersebut. Terlebih lagi saat ini kajian-kajian sunnah mulai berjalan dan praktik-praktik bid'ah mulai ditinggalkan seperti Maulid Nabi, Isra' mi'raj dan lain sebagainya. ${ }^{56}$

Aisya jamaah yang rutin mengikuti kajian mengaku bahwa dalam kehidupan sehari-harinya terjadi perubahan dalam aspek ibadah. Seperti sholat tepat waktu, rajin mengaji dan mulai menambah amalanamalan sunnah ${ }^{57}$. Menurut M.aliyul Hadi juga salah seorang jamaah

\footnotetext{
${ }^{56}$ Abdul Karim Mukram, Pembina Ta'mir Majid Jamik Al-Hidayah Batumarta, Martajaya, Wawancara, 4 Juli 2019

${ }^{57}$ Aisya Adila, Jamaah Kajian Rutin, Wawancara, Blok H Martajaya, 5 Juli 2019
} 
kajian mengatakan, semakin sering ikut kajian rutin di masjid menambah semangatnya untuk fastabikul khairat. ${ }^{58}$

Dari hasil penelitian yang penulis lakukan, penulis menilai bahwa masjid mempunyai harapan kepada masyarakat agar dapat menerapakan nilai-nilai keislam dalam kehidupan sehari-hari agar dapat berlakunya norma-norma Islam dalam kehidupan masyarakat desa Martajaya. Hal ini sama seperti pendapat Biddle dan Thomas bahwa ada sebuah tuntutan yang lama kelamaan dapat menjadi norma bagi yang memerankan.

\section{KESIMPULAN}

Berdasarkan hasil penelitian di atas, dapat disimpulkan bahwa Masjid Jamik Al-Hidayah memiliki peranan yang posistif Dalam Menanamkan Nilai-Nilai Keislaman di Desa Martajaya. Indikasi ini dapat ketahui dari Pertama, Harapan tentang peranan (Expectation), yaitu adanya harapan masyarakat kepada Masjid Jamik Al-Hidayah untuk tetap mengembangkan da'wahnya dalam menjalankan peranannya menamkan nilai-nilai keislaman di Desa Martajaya baik dari segi Akidah, syariah maupun akhlak, melaui pendidikan anak-anak, kajian-kajian rutin atau kegiatan-kegiatan lain yang diselenggarakan.

Kedua, dari aspek Norma yaitu berjalannya program-program yang diselenggarakan oleh masjid telah membawa pengaruh dan telah membentuk suatu norma atau kebiasan baru yang baik pada masyarakat. dari kegiatan kegiatan yang diselenggarakan oleh Masjid Jamik Al-Hidayah Batumarta sedikit demi sedikit mulai bisa dirasakan, dimulai dari sholat berjamaah yang kemudian membawa dampak bagi akhlak masing-masing jamaah terhadap tetangga, juga merubah akhlak anak-anak melalui ranah pendidikan, sedikit demi sedikit menghapuskan praktik bid'ah dan kesyirikan dimasyarakat melalui kajian-kajian rutin, khutbah jumat dan lainlain. Hal ini menunjukan bahwa aspek norma (kebiasaan) baik dari akidah, syariah maupun akhlak masjid tersebut telah memiliki berperan yang positif di masyarakat Desa Martajaya dapat.

${ }^{58}$ M.Aliyul Hadi, Jamaah Masjid Jamik Al-Hidayah Batumarta,

Wawancara, Martajaya 5 Juli 2019 
Ketiga. Performance (wujud prilaku) yaitu berjalanya programprogram yang telah terselenggara di Masjid Jamik AL-Hidayah Batumarta seperti program harian yaitu solat jamaah, kajian rutin $b a^{\prime} d a$ magrib, program mingguan seperti solat jum'at, kajian khusus ibu-ibu, program bulanan seperti bakti sosial, tablig akbar, atau pendidikan untuk anak yang setara dengan TK, Ma'had Tahfiz untuk anak-anak usia sekolah. Kegitan tersebut dapat menjadi bukti adanya wujud prilaku nyata yang dilakukan oleh Masjid Jamik Al-Hidayah dalam penanaman nilai-nilai keislaman baik dari segi akidah, syariah maupun akhlak kepada masyarakat Desa Martajaya.

\section{DAFTAR PUSTAKA}

Abdul Qadir Jawaz, Yazid, Prinsip Dasar Islam, Bogor: Pustaka At-Taqwa, 2010

al-Fauzan, Abdullah bin Shalih, Buku Pintar Masjid, Jakarta: Pustaka Imam Asy-Syafi'I, 2011

Al Mubarak Furi, Shafiurrahman, Ar-Rabiq Al-Makbtum, Jakarta Timur: Pustaka Al-Kautsar, 2012

Bidang Pemberdayaan Daerah \& Kerjasama Dalam Negeri Dewan Da'wah Islamiyah Indonesia, Panduan Pengelolaan Masjid \& Islamic Centre, Jakarta, 2013

Djazuli, Ilmu Fiqh, Jakarta: Kencana Prenada Media Group, 2010

Departemen pendidikan dan budaya, Kamus Besar Babasa Indonesia, Jakarta:

Balai Pustaka, 1988, hal. 751

Enjang AS dan Hajir, Etika Dakwah,Bandung: Widya Padjajaran, 2009

al-Fauzan, Shalih bin Fauzan bin Abdullah, Kitab Tauhid 1, Jakarta: Darul Haq, 2012,

Hafifudin, Didin, Dakwah Aktual,

Hamudu, Mahmud, Pedoman Menejemen Organisasi Jama'ah Masjid, Kendari: Unhalu Press, 2005 
Harahap, Sofyan Syafri, Menejemen masjid, Yogyakarta: PT. Dana Bhakti Wakaf, 1993

Kakka, Sudirman, Rekonstruksi Menejemen Masjid dan Peran Kelebean, Bima: Pemuda Kabupaten Bima, 2016

Mulyana, Deddy, Metodeologi Penelitian Kualitatif, Bandung: PT Remaja Rosdakarya, 2006

Nasution, Islam dan Problema-Problema Masyarakat, Jakarta: PT Bulan Bintang, 1988

Natsir, Mohammad, Fiqhud Da'wah, Jakarta: Yayasan Capita Selecta dan Media Da'wah, 2008

N. Grass, W. S. Masson and A.w.m.c. Eachern, Exploration Role Analysis, dalam david Berry, Pokok-pokok Pikiran dalam Sosiologi, Jakarta: Raja Grafindo Persada, 1995, cet. III, hal, 99

Rifai, A Bachrun dan Moch Fakhruroji, Menejemen Masjid, Bandung: Benang Merah Press, 2005

Saifuddin Anshari, Endang, Wawasan Islam, Jakarta: Gema Insani, 2004

Sarwono, Sarlito Wirawan, Teori-Teori Psikologi Sosial, Jakarta: Grafindo Persa, 2017

Sugiono, Metode Penelitian Menejemen, Bandung Bandung: Alfabeta, 2015

Suwaid, Muhammad, Mendidik Anak Bersama Nabi, Surakarta: Pustaka Arafah, 2017

Sugiono, memahami penelitian kualitatif, Bandung: Alfabeta, 2016

Soekanto, Soerjono, Sosiologi Suatu Pengantar, Jakarta: Rajawali Pers, 2009

Sulaiman Rasjid, figh Islam, Bandung: Sinar Baru Algensindo, 2013

Sarlito Wirawan Sarwono, Teori-teori Psikologi Sosial, Jakarta: PT Raja Grafindo Persada, 2017

Tim Pustaka Phoenix, Kamus Besar Bahasa Indonesia, Jakarta: Pustaka Phoenix, 2009 


\section{A. Wawancara}

Abdul Karim Mukram, Pembina Takmir Masjid Jamik Al-Hidayah Batumarta, Wawancara, Martajaya, 4 Juli 2019

Ahmad Romadhon, Pembina Takmir Masjid Al-Hidayah Batumarta, Wawancara, Batumarta 1, 12 Maret 2019

Aisya Adila, Jamaah Kajian Masjid Jamik Al-Hidayah Batumarta, Wawancara, Martajaya, 5 Juli 2019

Amanati Sholihah, Kepala Sekolah Tahlila, Wawancara, Dusun Tri Mulyo Desa Martajaya Lubuk Raja, 2019

Imam Sugiarto, Pemateri Kajian, Wawancara, Blok H Martajaya, 18 Maret 2019

Leyga Aini Prima Madusari, Pengajar Tahfidz Manarul Hidayah, Wawancara, Dusun Tri Mulyo Desa Martajaya Lubuk Raja, 27 Mei 2019

M. Aliyul Hadi, Jamaah Masjid Jamik Al-Hidayah Batumarta, Wawancara, Blok C Martajaya, 6 Juli 2019

Nur 'ilmi, Pemateri Kajian, Wawancara, Blok H Martajaya, 18 Maret 2019

Suwartiah, Jamaah kajian, Wawancara, Blok H Martajaya, 4 Juli 2019

Yusri Hamid, Ketua Pengurus, Wawancara, Dusun Tri Mulyo Desa Martajaya Lubuk Raja, 11 Maret 2019 
112 | Peranan masjid jamik... 